\title{
Tourists' Evaluations of Destination Image and Future Behavioural Intention: The Case of Malaysia
}

\author{
Mahadzirah Mohamad, Ahmad Rusdi Abdullah \& Safiek Mokhlis (Corresponding author) \\ Faculty of Management and Economics, Universiti Malaysia Terengganu \\ Kuala Terengganu 21030, Malaysia \\ Tel: 60-9-668-4823 E-mail: safiek@umt.edu.my
}

Received: October 11, $2011 \quad$ Accepted: October 31, $2011 \quad$ Published: March 1, 2012

doi:10.5539/jms.v2n1p181 URL: http://dx.doi.org/10.5539/jms.v2n1p181

This study was funded by the Ministry of Higher Education Malaysia under the Fundamental Research Grant Scheme (FRGS) vot no. 59191.

\begin{abstract}
The competitive situation and greater challenges within the tourism industry worldwide entail a better understanding of destination image and destination loyalty (future behavioural intention) to achieve Malaysia's apiration to retain its international reputation as one of the most desirable destinations in Asia and become a developed country in year 2020. The objectives of this study are to ascertain the perception of foreign tourists of Malaysia as a travel destination and determine the predicting factors that influence the formation of tourists' future behavioural intention. Therefore, this study examines the relationship between destination image and future behavioural intentions of foreign tourists to Malaysia. A quantitative methodology, using responses given by 1007 foreign tourists, was employed in the analysis. A multiple regression analysis was carried out in order to examine the relationship among the variables. The findings indicate that perceptions of Malaysia's attractions, accessibility and available package, heritage attraction and natural attraction are significant predictors of foreign tourists' intentions to revisit and their willingness to recommend the destination. The marketing implications of the study findings are discussed.
\end{abstract}

Keywords: Destination image, Tourism, Behavioural intention, Malaysia

\section{Introduction}

The rapid growth of international tourism over the past three decades has attracted considerable attention from the government, practitioners and researchers in many developing nations, including Malaysia. International tourism not only contributes foreign exchange to the host country but it is also an important employment generating activity and source of income (Liden \& Tyler, 1992). Acknowledging the great potentials in the tourism industry, it was identified as one of the National Key Economic Areas in the Government Transformation Program to achieve the country's Vision 2020 to become an advanced nation by year 2020 (PEMANDU, 2010).

Although tourism is recognised as an important economic contributor to the nation and the industry, but it is faced with an immense pressure to significantly play a crucial part in propelling the economy. The Malaysian tourism industry has been tested by several challenges. In 2003, for example, the number of the tourist arrivals was adversely affected, particularly by the outbreak of Severe Acute Respiratory Syndrome (SARS), as well as geopolitical uncertainties worldwide (Economic Planning Unit, 2006). Increased in oil prices and the global economic slowdown in 2008 worsen the situation and posed challenging times ahead within the industry. The unstable increase in tourists' arrivals from 2004 to 2010 supports the claim that the tourism industry is very competitive (Tourism Malaysia, 2011). Thus, effective strategy has to be put in place to ensure progressive growth within the industry to support the nation's aspiration to become a developed country in 2020. These changes within the environment and increasingly competitive international tourism industry call for an effective positioning strategy that would enhance the steady growth within the industry (Buhalis, 2000).

It is widely accepted that the tourism industry is identified as one of the major sources of economic growth 
(Habibi, Abdul Rahim, Ramchandran \& Chin, 2009). The major contributors to the development of tourism are the local and foreign tourists. At the international level, a stable growth in the tourists' arrivals would ensure continual growth within the industry. Therefore, the government through the Malaysia Tourism Promotion Board (Tourism Malaysia) has undertaken enthusiastic efforts promoting Malaysia especially at the international level to attract foreign tourists to Malaysia. However, according to the Bucket Theory of Marketing, attracting new tourists and increasing the revenue from existing customers are said to "fill the bucket". When tourists stop purchasing or decreased arrival for a period of time is portrayed as "there is a hole in the bucket". In order to plug up the leaks in the bucket, efforts should be undertaken to understand the post-behaviour intentions of foreign tourists. Despite the tourism increasing importance in the Malaysian economies, the study on post-visit behaviour intentions has attracted relatively little attention in the empirical literature on tourism marketing. Based on the above setting it is crucial to focus on examining existing tourists' future behaviour exhibited through their intention to return (purchase intention/loyalty) and recommendation through word-of-mouth (WOM). The move to study behaviour intention is meeting the desire to understand factors that lead to customer retention.

Hence, the main aims of this study are to firstly, capture the perceived image of Malaysia as a travel destination among foreign tourists and measure their post-visit behaviour intention. Secondly, the study attempts to examine the predicting role of destination image on the formation of future behavioural intention of foreign tourists. The study extends the current literature on this relationship by providing empirical evidence of their applicability in the Malaysian context. Investigating the perception of foreign tourists towards Malaysia as a preferred holiday destination would provide useful insights to Destination Management Organization (DMO), tourism marketers and tourist offices in projecting the right image of Malaysia as one of the world's premier travel destinations.

This rest of this article is structured as follows. In section two, a review of previous research is presented. Section 3 provides details of the methodology that was used. Section 4 contains the results whilst, in Section 5, implications are explored and conclusions drawn.

\section{Literature review}

\subsection{Destination image}

Destination image is an important concept in tourism marketing literature which should be developed through marketing research. Previous works on this topic provide a narrow definition of destination which described it as well-defined geographical areas such as a country, an island or a town (Hall, 2000; Davidson \& Maitland, 1997). However, recent definition of destination expands to include a perceptual concept of destination which can be interpreted subjectively by tourists depending on their travel itinerary, cultural background, purpose of visit, educational level and past experience. According to Buhalis (2000), tourism destination consists of six components: attractions (natural, man-made, artificial, purpose built, heritage, special events), accessibility (entire transportation system comprising of routes, terminals and vehicles), amenities (accommodation and catering facilities, retailing, other tourists service), activities (all activities available at the destination and what consumers will do during their visits), ancillary services (services used by tourists such as banks, telecommunication, post, newsagent, hospital, etc.) and available packages (pre-arranged packages by intermediaries and principals). According to Choi et al. (1999), destination image is people's belief, idea or impression about a place. This definition is parallel to the one defined by Echtner and Ritchie (1993) as consisting two main components comprising those that are attribute-based and those that are holistic. Each of these components contains functional, more tangible aspects of destination image, and psychological represent the more abstract aspects of destination image characteristics.

Positioning a tourism destination can gain a competitive edge but prior to that, the target market's perception of Malaysia as a travel destination has to be ascertained. Destination image guides promotional activities of a destination. The concept of positioning is not limited to a brand, company, service, person, but is also applicable to a place (Kotler, 2000). Successful positioning strategy requires host country's DMO to ascertain main attributes of the destination that are attractive from customer's mind and develop appropriate destination positioning strategy based on the identified image for the right target markets. Moreover, Buhalis (2000) posits that selecting the right target market and offering the most suitable combination of local tourism products and services is the success for destination marketing. Hence, it is important to ascertain the Malaysia's destination image from the customers' perspective which can be used to guide promotional activities to attract foreign tourist travelling to Malaysia.

Therefore, it was postulated that:

H1: Malaysia destination image is manifested by several underlying dimensions. 


\subsection{Destination image and behavioural intentions}

The milestone of general interpretation of behavioural intentions is established by Zeithaml et al. (1996). The researchers suggest that favorable behavioural intentions are associated with a service provider's ability to get its customers to: (1) Say positive things about them, (2) recommend them to other customers, (3) remain loyal to them, (4) spend more with them, and (5) pay price premiums. A number of subsequent studies have used one or more of these five proposed constructs to examine the outcomes of successful business. For instance, Baker and Crompton (2000) used items adapted from the scale developed by Zeithaml et al. (1996) to operationalise behavioural intention in the exploration of its relationship with the perceived performance quality. Cronin et al. (2000) undertake to examine the effects of quality, value, and customer satisfaction on behaviour intention using items measuring the underlying behavioural intentions dimensions postulated by Zeithaml et al. (1996). Kuenzel and Katsaris (2009) summarise post-visit behaviour into two dimension namely, intention to return (purchase intention/loyalty) and recommendation through word-of-mouth (WOM). The importance of WOM communication in service sector is documented in several studies (Davis et al. 1978; Day, 1980; George \& Berry, 1981; Hartline \& Jones, 1996; Zeithaml et al. 1993).

Interestingly, studies such as Hunt (1975) and Pearce (1982) have illustrated that there is a positive relationship between destination image and behavioural intention. Recent work of Tasci and Gartner (2007) demonstrates destination image is an independent variable that has an influence on behavioural intention. The findings is parallel to the work of Bigne, Sanchez, and Sanchez (2001) who found that tourism image is a direct antecedent of perceived quality, satisfaction, intention to return and willingness to recommend the destination. Moreover, Chen and Tsai (2007) suggest that destination image have both direct and indirect effects on behavioural intentions. Positive destination image will result in tourist's satisfaction and has an influence on tourist behaviour intentions (Chi \& Qu, 2008). However, it is argued that tourists' overall experience consuming a combination of local tourism products and services develop their image of a destination after their visitation (Buhalis, 2000), thus perceived attractiveness, rather than overall satisfaction, is the antecedent of revisit intention (Um, Chon \& Ro, 2006). According to Gover, Go and Kumar (2007) successful marketing communication strategies can significantly influence travel behaviour further illustrates that destination image has an influence on behavioural intention. Based on the above arguments we hypothesize the following:

H2: Tourist behavioural intention is exhibited by two underlying dimensions of Recommendation and Revisit intention.

H3: The more favourable the destination image, the more positive the loyalty intention.

\section{Methodology}

To carry out this research, a personal interview was conducted by means of a structured questionnaire. The first part of the questionnaire consists of 53 statements to measure respondents' perception towards Malaysia's image as tourist destination. The scale that was designed by Echtner (1991) was used in entirety in this study. The respondents were asked to rate their level of agreement with each statement using ten-point scale ranging from 1 (Strongly Disagree) to 10 (Strongly Agree). The second part of the questionnaire was designed to gather information about respondents' behavioural intention. It consists of six statements, adapted from Lin (2006) and were measured with reference to a ten-point rating scale, ranging from 1 (Least Likely) to 10 (Most Likely). The last section of the questionnaire contains questions on the profile of respondents, which is important to provide insights related to their background and characteristics.

The target population surveyed included those foreign tourists who departed from two major airports of Malaysia: Kuala Lumpur International Airport (KLIA) which is the hub for Malaysian Airline System (MAS) and Low Cost Carrier Terminal (LCCT) which is the hub for Air Asia Airlines. Since accurate size of the population cannot be easily ascertained, a probability sampling procedure could not be used. Instead, a purposive sampling method was employed by targeting respondents that meet the following inclusion criteria: (1) foreign tourists who visited Malaysia for leisure or business, and (2) who have stayed for at least one day but less than one year (Mill \& Morisson, 1985).The survey was conducted in three phases (July 2010, December 2010 and March 2011) during the "peak" seasons of tourist arrivals to Malaysia. Self-administered questionnaires were distributed to respondents by trained enumerators at the resting areas in the Departure Halls. In general, respondents were responsive and willing to participate, and refusal rates were relatively low. In total, 1051 questionnaires were obtained from the exercise. The returned questionnaires were carefully checked, and those with excessive missing data were discarded, resulting in 1007 usable questionnaires. Data analyses were conducted using SPSS statistical software version 17 for Windows. 


\section{Results}

\subsection{Sample characteristics}

Table 1 presents the frequency distribution of the respondents' demographic profile. The sample consisted of 1007 respondents of which 59.6 percent were males, with the largest age group between 21 and 30 years old (37.7\%). Regarding marital status, the majority of the respondents in the study were married (45.7\%). Most of the respondents hold a bachelor degree (40.3\%). About half of the respondents $(47.3 \%)$ indicated that the trip to Malaysia was their first time visit.

\subsection{Factor analysis}

Multiple items measuring destination image and behavioural intention were factor analyzed to reduce the numerous variables to a manageable number of components. Such analysis is useful in gaining understanding on the main dimensions that underlie the observed sets of items (Hair, Anderson, Tatham \& Black, 2010). Principal components factor analysis with a varimax rotation was used to factor the multiple items. Factoring ceased when all eigenvalues of greater than one were obtained and when a set of factors explained a large percentage of the total variance is achieved. An accepted method of interpretation of factor loadings is to regard as significant any variable with a loading of 0.5 or greater are associated with the appropriate factor (Hair et al. 2010). To examine the internal consistency of the factors obtained, Cronbach's alpha was calculated where a coefficient at 0.7 or higher was considered acceptable (Nunnally, 1976). Table 2 summarises the results.

The factor analysis of the 53 destination image items yielded a five principal components solution. Each one of these five factors had an eigenvalue which was greater than one. Table 2 shows the resultant factor and the Cronbach's alpha coefficients (due to space limitations, only a summary of the result is presented). Following a close inspection of the items on each factor, the five factors were summarily named as follows: Accessibility and Available package (7 items), Attractions (7 items), Amenities and Activities (6 items), Heritage attraction (3 items) and Nature attraction ( 2 items). These factors produced Cronbach's alphas ranged from 0.73 to 0.81 ; indicating high internal consistencies and reliabilities.

Accessibility and Available package refers to Malaysia is being perceived as a safe and good place to visit because of good quality restaurants and hotels with high standards of cleanliness and hygiene, including the availability of packaged vacation and good tourist information. The term Attraction means Malaysia is perceived to be offering an adventurous and fascinating destination, with many places of interest to visit that include its architecture, impressive scenery, unique customs and culture. The factor labeled as Amenities and Activities reflects tourists' perception that Malaysia has first class hotels and restaurants whilst provide opportunities to learn new things from the organized festival and celebrations, and its historical places. Heritage attraction refers to the local architectural styles and foods in Malaysia. The final factor, Nature attraction means Malaysia is known for its good beaches.

Similar procedures were also applied to the behavioural intention items. Factor analysis and varimax rotation methods extracted two factors which had eigenvalues greater than one. As Table 2 shows, these factors produced Cronbach's alpha coefficients of 0.92 and 0.78 respectively, indicating high internal consistencies and reliabilities. These two factors were labeled as Recommendation and Revisit Intention. Thus, we conclude that behavioural intention is exhibited by two underlying dimensions, Recommendation and Revisit intention. The term Recommendation refers to tourists will engage in saying positive things about Malaysia. Moreover, they will recommend and encourage their friends to visit Malaysia. The second factor, Revisit intention reflects tourists' considering Malaysia as their choice of future visit and plan to come back again.

\subsection{Multiple regression analysis}

To identify which destination image dimensions were correlated strongly with behavioural intention, two multiple regression analyses were performed using five destination image dimensions as independent variables. The dependent variables were the factor scores for the two behavioural intention factors, recommendation and revisit intention. An automated selection procedure of stepwise regression was applied to find the best regression model.

To test whether the assumptions of linearity, homoscedasticity and independence were met by the data, checks were undertaken by constructing the normal probability plot and residuals scatter plot. A visual inspection of the normal probability plot revealed that the residual plots were almost close to the normal straight diagonal line, suggesting that the residuals were approximate normal distribution. Additionally, the scatter plot (a plot of the studentised residuals versus the predicted values) revealed that most of the plots concentrated along the zero line in an almost rectangular shape, with relatively equal dispersion about zero and no strong tendency to be either 
greater or less than zero, verifying that the residuals were linear and homoscedastic. Thus there were no reasons to be concerned about the violation of regression assumptions.

To test for the possible presence of multicollinearity problem, the tolerance values of the independent variables were assessed while the regression analysis was run using the conventional value of 0.1 as the cut-off point for high multicollinearity (Hair et al. 2010). The analysis showed that all independent variables in the regression equation had high tolerance values ranging from 0.64 to 0.92 and the VIF values are all quite close to 1.0 (the highest was 1.55 ), indicating an absence of multicollinearity problem.

\subsubsection{Relationship between destination image and recommendation}

Table 3 presents the results of the multiple regression analysis with Recommendation as the dependent measure. The overall $F$-test for the final regression model was highly significant $(F=276.7, p<0.001)$, with three destination image dimensions entered the resulting equation: Attractions $(\beta=0.51, p<0.001)$, Accessibility and Available package $(\beta=0.2, p<.001)$, and Natural attraction $(\beta=0.10, p<0.001)$. The explanatory power of this model, as reported by the adjusted $\mathrm{R}^{2}$ value was 0.47 , suggesting that 46.7 percent of the variability in the Recommendation was predicted by the destination image dimensions. According to Cohen (1988, p. 79-81), this effect size can be considered as large.

Stepwise ordering of destination image dimensions that entered the regression equation is as follows. Attraction was the first variable that entered the equation as it was the most salient in explaining Recommendation. It alone contributes 42.1 percent of the variation. At Step 2, Accessibility and Available package entered the regression equation and it improved the predictive efficiency of Recommendation (R-square) from 42.1 to 45.6 percent. Natural attraction, the next variable to enter the equation at Step 3, accounted for an additional 9 percent of the variation.

The relative importance of the destination image dimensions was indicated by their Standardized Beta Coefficients. As is evidence from Table 3, the strongest impact on Recommendation was by Attractions ( $\beta=$ $0.51)$. The next most important was Accessibility and Available package $(\beta=0.20)$, followed by Natural attraction $(\beta=0.10)$.

\subsubsection{Relationship between destination image and revisit intention}

Table 4 summarises the results of the multiple regression analysis with Revisit Intention as the dependent measure. As the table indicates, the final regression model with Revisit Intention as dependent variable was found to be statistically significant $(\mathrm{F}=63.74, \mathrm{p}<0.001)$. Four destination image variables entered the final regression equation: Accessibility and Available package $(\beta=0.21, p<0.001)$, Attractions $(\beta=0.21, p<0.001)$, Heritage attraction $(\beta=0.19, p<0.001)$, and Natural attraction $(\beta=0.06, p<0.05)$. The explanatory power of this model, as reported by the adjusted $\mathrm{R}^{2}$ value was 0.208 , indicating that 21.8 percent of the variability in Revisit Intention could be explained by the independent variables.

Accessibility and Available package emerged as the major predictor as it was highly significant in explaining Revisit Intention (14.6 percent). This was followed by Attractions and accounted for an additional 3 percent of the variation in Revisit Intention. At Step 3, Heritage attraction entered the regression equation and accounted for an additional 2.9 percent of the variation in Revisit Intention. Natural attraction entered the regression equation at Step 4 and accounted for only 0.3 percent of the variation in Revisit Intention.

The relative importance of the Destination Image dimensions was indicated by their Standardized Beta Coefficients. As is evidence from Table 4, the strongest impact on Revisit Intention was by Attractions $(\beta=0.21)$ and Accessibility and available package $(\beta=0.21)$. This was followed by Heritage attraction $(\beta=0.19)$ and Natural attraction $(\beta=0.06)$.

The above findings suggest that $\mathrm{H} 3$ is supported, indicating that the more favourable the destination image the more positive the loyalty intention which measured by two underlying dimension namely Recommendation and Revisit intention.

\section{Conclusion}

The study was conducted with the purpose of identifying significant relationships between foreign tourists' evaluations of Malaysia's destination image and their future behavioural intention. The results of this study underline that destination marketers must take particular consideration of the image factor as this will affect tourists' behavioural intention. Positive relationship between destination image and behavioural intentions was highlighted. The findings suggest that if foreign tourists perceived favourable destination image, they are more willing to spread positive recommendations as well as to undertake repeat visitations in future. Interestingly, the 
study uncovers the dimensions of Malaysia's destination image which are manifested by five underlying factors similar to the ones proposed by Buhalis (2000). Therefore, DMO is suggested to capitalize on these dimensions when promoting Malaysia at the international level. On the other hand, behavioural intention is exhibited by two underlying dimensions of Recommendation and Revisit intention as posited by Kuenzel and Katsaris (2009).

From a practical standpoint, the findings offer important implications for the development of destination marketing strategies. In today's competitive climate, creating and managing the right destination image have become vital for effective positioning and differentiation. More specifically, destination marketers should concentrate on formulating effective tourism packages, which address the expectations, needs and concerns of tourists and project Malaysia as an attractive tourist destination. Results of this study reveal that examining the behaviour intentions of foreign tourists, which are influenced by favourable destination image, provides better understanding of tourist retention. Malaysia is moving in the right direction in terms of image consolidation and enhancement; however, further refinement is imperative to ensure continuous inflow of the right segments of tourists into the country.

This study has some limitations that need to be taken into account when considering the study findings. The study findings are specific to foreign tourists and cannot be generalised to domestic tourist populations. If the responses from the domestic tourists have also been collected, it would provide a more comprehensive picture of tourism industry in Malaysia. Also, in this research, investigations of the relationships between destination image and behavioural intentions were carried out at the postconsumption behaviour stage. Although statistically significant relationships were found between these two constructs, the magnitude of the effects may be different at the prepurchase evaluation stage. Thus, further research should investigate whether nonvisitors' evaluations of destination image and its effect on postconsumption behaviour are different from that of visitors' perceptions.

\section{References}

Baker, D. A., \& Crompton, J. L. (2000). Quality, satisfaction and behavioral intentions. Annals of Tourism Research, 27(3), 785-804. http://dx.doi.org/10.1016/S0160-7383(99)00108-5

Bigne, J. E., Sanchez, M. I., \& Sanchez, J. (2001). Tourism image, evaluation variables and after purchase behavior: Interrelationship. Tourism $\quad$ Management, $22(6), \quad$ 607-616. http://dx.doi.org/10.1016/S0261-5177(01)00035-8

Buhalis, D. (2000). Marketing the competitive destination of the future. Tourism Management, 21(1), 97-116. http://dx.doi.org/10.1016/S0261-5177(99)00095-3

Chen, C. F., \& Tsai, D. (2007). How destination image and evaluative factors affect behavioral intentions? Tourism Management, 28(4), 1115-1122. http://dx.doi.org/10.1016/j.tourman.2006.07.007

Chi, C. G., \& Qu, H. (2008). Examining the structural relationships of destination image, tourist satisfaction and destination loyalty: An integrated approach. Tourist Management, 29(4), 624-636. http://dx.doi.org/10.1016/j.tourman.2007.06.007

Choi, W. M., Chan, A., \& Wu, J. (1999). A qualitative and quantitative assessment of Hong Kong's image as a tourist destination. Journal of Tourism Management, 20(3), 361-365. http://dx.doi.org/10.1016/S0261-5177(98)00116-2

Cohen, J. (1988). Statistical power analysis for the behavioral sciences (2nd ed.). New York: Academic Press.

Cronin, J. J., Brady, M. K., \& Hult, G. T. M. (2000). Assessing the effects of quality, value and customer satisfaction on consumer behavioral intentions in service environments. Journal of Retailing, 76, 193-201. http://dx.doi.org/10.1016/S0022-4359(00)00028-2

Davidson, R., \& Maitland, R. (1997). Tourism destinations. London: Hodder and Stoughton.

Davis D. L., Guiltinan, J. G., \& Jones, W. H. (1978). Services characteristics, consumer research and the classification of retail services. Journal of Retailing, 55(Fall), 3-21.

Dube, L., Renaghan, L., \& Miller, J. (1994). Measuring customer satisfaction for strategic management. Cornell Hotel and Restaurant Administration Quarterly, 35(1), 39-47. http://dx.doi.org/10.1016/0010-8804(94)90063-9

Echtner, C. M. (1991). The measurement of tourism destination image. Unpublished MBA thesis, University of Calgary, Alberta.

Echtner, C. M., \& Ritchie, J. R. (1993). The measurement of destination image: An empirical assessments. Journal of Travel Research, 31(4), 3-13. http://dx.doi.org/10.1177/004728759303100402

Economic Planning Unit (2006). Ninth Malaysian Plan 2006-2010. Putrajaya: Prime Minister's Department. 
George, W. R., \& Berry, L. L. (1981). Guidelines for the advertising of services. Business Horizon, 24(May-June), 52-56. http://dx.doi.org/10.1016/0007-6813(81)90056-2

Govers, R., Go, F. M., \& Kumar, K. (2007). Promoting tourism destination image. Journal of Travel Research, 11(2), 199-217.

Habibi, F., Abdul Rahim, K., Ramachandran, S., \& Chin, L. (2009). Dynamic model for international tourism demand for Malaysia: Panel data evidence. International Research Journal of Finance and Economics, 33, 207-217.

Hair, J., Anderson, R., Tatham, R., \& Black, W. (2010). Multivariate data analysis (7th ed.). Upper Saddle River, NJ: Prentice-Hall.

Hall, C. M. (2000). Tourism planning: Policies, processes and relationships. Essex: Prentice Hall.

Hartline, M. D., \& Jones, K. C. (1996). Employee performance cues in a hotel service environment: influence on perceived service quality, value and word-of-mouth intentions. Journal of Business Research, 35, 207-215. http://dx.doi.org/10.1016/0148-2963(95)00126-3

Hunt, J. D. (1975). Image as a factor in tourism development. Journal of Travel Research, 13(3), 1-7. http://dx.doi.org/10.1177/004728757501300301

Kotler, P. (2000). Marketing management (11th ed.). New Jersey: Pearson Education.

Kuenzel, S., \& Katsaris, N. (2009). A critical analysis of service recovery processes in the hotel industry. TMC Academic Journal, 4(1), 14-24.

Leisen, B. (2001). Image segmentation: The case of a tourism destination. Journal of Services Marketing, 15(1), 49-66. http://dx.doi.org/10.1108/08876040110381517

Liden, J., \& Tyler, C. (1992). Tourism: Stay awhile, spend some more. Euromoney (Malaysia Supplement). Journal of Hospitality and Tourism Research, 116(376), 108-111.

Lin, I. H. (2006). Perception of Service Failure, Service Recoveries Strategies and Behavioral Intentions of Hotel Guests in Orlando, Florida. Unpublished PhD Dissertation, Lynn University, Florida.

Mill, R. C., \& Morisson, A. (1985). The tourism system. Hemel Hempstead: Prentice Hall.

Nunnally, J. (1976). Psychometric theory. New York: John Wiley \& Sons.

Pearce, P. L. (1982). Perceived changes in holiday destinations. Annals of Tourism Research, 9, 145-164. http://dx.doi.org/10.1016/0160-7383(82)90044-5

Performance Management \& Delivery Unit (PEMANDU), Prime Minister's Department (2010). Government Transformation Program - The Roadmap. Kuala Lumpur: Percetakan Nasional Malaysia Berhad.

Tasci, A. D. A., \& Gartner, W. C. (2007). Destination image and its functional relationships. Journal of Travel Research, 45(4), 413-425. http://dx.doi.org/10.1177/0047287507299569

Tourism Malaysia. (2011). Research facts and figure. [Online] Available: http://corporate.tourism.gov.my/research.asp?page=facts_figures (October 27, 2011)

Um, S., Chon, K., \& Ro, Y. (2006). Antecedents of revisit intention. Annals of Tourism Research, 33(3), 1141-1158. http://dx.doi.org/10.1016/j.annals.2006.06.003

Zeithaml, V. A., Berry, L. L., \& Parasuraman, A. (1993). The nature and determinants of customer expectation of service. Journal of the Academy of Marketing Science, 21(1), 1-12. http://dx.doi.org/10.1177/0092070393211001

Zeithaml, V. A., Bitner, L. L., \& Parasuraman, A. (1996). The behavioural consequences of service quality. Journal of Marketing, 60(April), 31-46. http://dx.doi.org/10.2307/1251929 
Table 1. Sample characteristics

\begin{tabular}{|c|c|c|c|}
\hline Characteristic & Category & $\mathrm{n}$ & $\%$ \\
\hline \multirow[t]{2}{*}{ Gender } & Male & 601 & 59.7 \\
\hline & Female & 406 & 40.3 \\
\hline \multirow[t]{6}{*}{ Age } & Below 20 & 64 & 6.4 \\
\hline & $21-30$ & 380 & 37.7 \\
\hline & $31-40$ & 213 & 21.2 \\
\hline & $41-50$ & 156 & 15.5 \\
\hline & $51-60$ & 122 & 12.1 \\
\hline & Over 61 & 72 & 7.1 \\
\hline \multirow[t]{6}{*}{ Marital Status } & Single & 350 & 34.3 \\
\hline & Living with partner & 162 & 15.9 \\
\hline & Married & 466 & 45.7 \\
\hline & Divorced & 13 & 1.3 \\
\hline & Separated & 4 & 0.4 \\
\hline & Widowed & 9 & 0.9 \\
\hline \multirow[t]{6}{*}{ Education } & Certificate & 124 & 12.3 \\
\hline & Diploma & 149 & 14.8 \\
\hline & Bachelor degree & 406 & 40.3 \\
\hline & Master degree & 218 & 21.6 \\
\hline & $\mathrm{PhD}$ & 42 & 4.2 \\
\hline & Other & 68 & 6.8 \\
\hline \multirow[t]{6}{*}{ Trip to Malaysia } & $1^{\text {st }}$ time & 482 & 47.3 \\
\hline & $2^{\text {nd }}$ time & 192 & 18.8 \\
\hline & $3^{\text {rd }}$ time & 97 & 9.5 \\
\hline & $4^{\text {th }}$ time & 39 & 3.8 \\
\hline & $5^{\text {th }}$ time & 21 & 2.1 \\
\hline & $>5^{\text {th }}$ time & 176 & 17.3 \\
\hline
\end{tabular}

Table 2. Results of factor analysis

\begin{tabular}{|l|c|c|c|c|c|}
\hline Factor & $\begin{array}{c}\text { No. } \\
\text { Item }\end{array}$ & $\begin{array}{c}\text { Eigen- } \\
\text { value }\end{array}$ & $\begin{array}{c}\text { Factor } \\
\text { loadings }\end{array}$ & $\begin{array}{c}\text { \% variance } \\
\text { explained }\end{array}$ & $\begin{array}{c}\text { Cronbach's } \\
\text { Alpha }\end{array}$ \\
\hline Destination Image & & & & & \\
\hline Accessibility \& Available package & 7 & 5.81 & $0.54-0.69$ & 14.82 & 0.79 \\
\hline Attractions & 7 & 3.07 & $0.53-0.71$ & 12.59 & 0.81 \\
\hline Amenities \& Activities & 6 & 1.94 & $0.60-0.77$ & 11.18 & 0.76 \\
\hline Heritage attraction & 3 & 1.47 & $0.73-0.81$ & 8.34 & 0.73 \\
\hline Natural attraction & 2 & 1.23 & $0.82-0.87$ & 7.18 & 0.79 \\
\hline Behavioural Intentions & & & & & 0.92 \\
\hline Recommendation & 3 & 3.23 & $0.89-0.91$ & 50.92 & 0.78 \\
\hline Revisit Intention & 2 & 1.03 & $0.86-0.89$ & 34.26 & 0.26 \\
\hline
\end{tabular}


Table 3. Stepwise regression results of destination image with recommendation

\begin{tabular}{|c|c|c|c|c|c|c|c|}
\hline Model & Predictor & $\mathrm{B}$ & Beta $(\beta)$ & $\mathrm{t}$-value & $p$-value & $F$ & Adj. $\mathrm{R}^{2}$ \\
\hline \multirow{2}{*}{1} & (Constant) & 1.95 & & 8.31 & .000 & 691.11 & 0.421 \\
\cline { 2 - 8 } & Attraction & 0.85 & 0.65 & 26.29 & .000 & & \\
\hline \multirow{2}{*}{3} & (Constant) & 1.15 & & 4.66 & .000 & 400.36 & 0.456 \\
\cline { 2 - 9 } & Attractions & 0.69 & 0.53 & 18.97 & .000 & & \\
\cline { 2 - 9 } & $\begin{array}{c}\text { Accessibility \& } \\
\text { Available package }\end{array}$ & 0.28 & 0.22 & 7.99 & .000 & & \\
\cline { 2 - 9 } & AtConstant) & 1.01 & & 4.07 & .000 & 276.70 & 0.465 \\
\cline { 2 - 9 } & $\begin{array}{c}\text { Accessibility \& } \\
\text { Available package }\end{array}$ & 0.25 & 0.20 & 6.99 & .000 & & \\
\cline { 2 - 9 } & Natural attraction & 0.08 & 0.10 & 4.05 & .000 & & \\
\hline
\end{tabular}

Table 4. Stepwise regression results of destination image with revisit intention

\begin{tabular}{|c|c|c|c|c|c|c|c|}
\hline Model & Predictor & $\mathrm{B}$ & $\operatorname{Beta}(\beta)$ & t-value & $p$-value & $F$ & Adj. $R^{2}$ \\
\hline \multirow[t]{2}{*}{1} & (Constant) & 1.21 & & 2.99 & .003 & 164.87 & 0.146 \\
\hline & $\begin{array}{c}\text { Accessibility \& } \\
\text { Available package }\end{array}$ & 0.74 & 0.38 & 12.84 & .000 & & \\
\hline \multirow[t]{3}{*}{2} & (Constant) & 0.39 & & -0.81 & .420 & 103.07 & 0.176 \\
\hline & $\begin{array}{c}\text { Accessibility \& } \\
\text { Available package }\end{array}$ & 0.54 & 0.28 & 8.13 & .000 & & \\
\hline & Attractions & 0.42 & 0.20 & 5.95 & .000 & & \\
\hline \multirow[t]{4}{*}{3} & (Constant) & -0.92 & & -1.93 & .054 & 83.41 & 0.205 \\
\hline & $\begin{array}{c}\text { Accessibility \& } \\
\text { Available package }\end{array}$ & 0.43 & 0.22 & 6.31 & .000 & & \\
\hline & Attractions & 0.46 & 0.23 & 6.66 & .000 & & \\
\hline & $\begin{array}{l}\text { Heritage } \\
\text { Attraction }\end{array}$ & 0.24 & 0.18 & 6.04 & .000 & & \\
\hline \multirow[t]{5}{*}{4} & (Constant) & -1.07 & & -2.21 & .027 & 63.74 & 0.208 \\
\hline & $\begin{array}{c}\text { Accessibility \& } \\
\text { Available package }\end{array}$ & 0.40 & 0.21 & 5.71 & .000 & & \\
\hline & Attractions & 0.44 & 0.21 & 6.19 & .000 & & \\
\hline & Heritage attraction & 0.25 & 0.19 & 6.16 & .000 & & \\
\hline & Natural attraction & 0.08 & 0.06 & 1.98 & .048 & & \\
\hline
\end{tabular}

